Journal Economics and Management (JECMA)

Volume 1, No. 02, Februari 2021, p. 37-41

\title{
Analisis Pengaruh Kepuasan Pelanggan Melalui Kualitas Produk Tape Ketan Daun Jambu
}

\author{
Analysis of The Influence of Customer Satisfication Through Product Quality Ketan \\ Daun Jambu
}

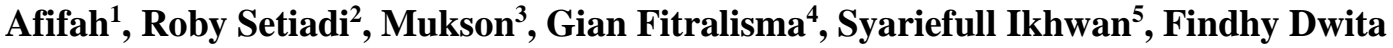 \\ Kumala $^{6}$ \\ 1,2,3,4,5 Program Studi Manajemen, Fakultas Ekonomi dan Bisnis, Universitas Muhadi Setiabudi, \\ Indonesia \\ ${ }^{6}$ Program Studi Ilmu Gizi, Fakultas Ilmu Kesehatan, Universitas Muhadi Setiabudi, Indonesia \\ e-mail: ${ }^{1}$ afifahtunnicha@gmail.com, ${ }^{2}$ robysetiadi@umus.ac.id, ${ }^{3}$ mukson.brebes@gmail.com, \\ ${ }^{4}$ gianfitralisma@umus.ac.id, ${ }^{5}$ syarief97tmi@gmail.com, ${ }^{6}$ indhydwita2401@gmail.com,
}

\begin{abstract}
ABSTRAK
Penelitian ini dilakukan untuk mengetahui serta mengukur kepuasan pelanggan melalui kualitas produk tape ketan daun jambu di Banjarharjo Kabupaten Brebes dengan menggunakan metode penelitian kuantitatif assosiatif. Peneliti membuat serta menyebar kuesioner kepada 30 responden yang merupakan sampel dari jumlah populasi pelanggan tape ketan daun jambu yang berada di Kecamatan Banjarharjo untuk dapat diteliti serta dianalisis sesuai dengan data yang telah disebar. Teknik analisis data pada penelitian ini menggunakan Uji Validitas, Uji Reliabilitas, Uji Regresi Sederhana, Uji Determinasi (R) dan Uji Hipotesis (Uji-t). Hasil distribusi responden penelitian ini adalah persepsi responden Kualitas Produk Tape Ketan Daun Jambu "Dio" memiliki nilai distribusi responden sebesar 4,11 dan masuk pada kategori interpretasi baik, dan persepsi responden terhadap kepuasan pelanggan tape ketan daun jambu "Dio" memiliki nilai distribusi responden dengan total 3,87 dan masuk pada kategori interpretasi puas. Sedangkan hasil pengujian yang diperoleh terdapat pengaruh positif kuat dan siginifikan antara kualitas produk Tape Ketan daun Jambu "Dio" terhadap kepuasan pelanggan. Hal ini dapat dilihat dari model Regresi Linier Sederhana $Y=4,477+1,616 X$, nilai koefisien korelasi $r=0,408$, kontribusi variabel kualitas produk terhadap variabel kepuasan pelanggan sebesar $16,6 \%$, pengaruh kualitas produk terhadap kepuasan pelanggan signifikan karena $t$ hitung > t tabel $(3,128>1,701)$.
\end{abstract}

Kata kunci: kualitas produk, kepuasan pelanggan, tape ketan

\begin{abstract}
This research was conducted to determine and measure customer satisfaction through the product quality of jambu leaf sticky rice in Banjarharjo, Brebes Regency by using associative quantitative research methods. Researchers made and distributed questionnaires to 30 respondents who were samples of the total population of jambu leaf sticky rice customers in Banjarharjo District to be researched and analyzed according to the data that had been distributed. The data analysis technique used in this research is validity test, reliability test, simple regression test, determination test $(R)$ and hypothesis test (t-test). The results of the distribution of respondents in this study were respondents 'perceptions of the quality of the "Dio" Tape Ketan Daun Jambu "Product" which has a respondent distribution value of 4.11 and is included in the category of good interpretation, and the respondents' perceptions of customer satisfaction with the "Dio" guava sticky rice tape have a distribution value of respondents with a total of 3.87 and entered the category of satisfied interpretation. While the test results obtained there is a strong and significant positive influence between the product quality of Tape Ketan Jambu "Dio" leaves on customer satisfaction. This can be seen from the Simple Linear Regression model Y $=4.477+$ $1.616 X$, the correlation coefficient $r=0.408$, the contribution of the product quality variable to the customer satisfaction variable is $16.6 \%$, the effect of product quality on customer satisfaction
\end{abstract}

Submitted: 2021, Accepted: 2021, Published: Februari 2021

ISSN: 2746 - 0568 (online), Website: http://jurnal.umus.ac.id/index.php/jecma 
Journal Economics and Management (JECMA), Volume 1, No. 1, Agustus 2021, p. 37-41

is significant because $t>$ t table $(3,128>1,701)$.Keywords: product quality, customer satisfaction, sticky tape

\section{INTRODUCTION}

Dalam kegiatan jual beli kepuasan pelanggan adalah sesuatu yang penting dan harus diperhatikan oleh pihak penjual atau perusahaan dalam melakukan aktivitas berbisnis, baik perusahaan dengan skala kecil, skala menengah maupun perusahaan dengan skala besar. Salah satu industri yang merupakan pilar ekonomi kerakyatan adalah industri UMKM. Industri UMKM yang sedang berkembang salah satunya bidang kuliner. Usaha kuliner tape ketan adalah salah satu produk yang pada umumnya diproduksi oleh home industry. Usaha kuliner ini masih bersifat tradisonal dengan mengangkat keunikan lokal sebagai sebuah ciri khas suatu daerah di Indonesia. Kegiatan usaha ini termasuk dalam kategori usaha kecil dan menengah yang memiliki tantangan dalam bidang pemasaran, sehingga perusahaan harus dapat mengenalkan produk dengan menggunakan biaya yang efisien guna memasarkan produk-produknya.

Salah satu usaha kuliner tape ketan yang akan kami analisis adalah usaha tape ketan khas Desa Banjarharjo Kecamatan Banjarharjo Kabupaten Brebes. Tape ketan khas Banjarharjo Brebes ini merupakan sebuah produk dengan komposisi beras ketan sebagai bahan baku utama yang diolah melalui proses permentasi (peragian) dan dibungkus menggunakan daun jambu sehingga memiliki cita rasa yang khas dibandingkan dengan produk lainnya sehingga menjadi sebuah positioning dalam pemasaran. Hal itu adalah salah satu keunggulan karena konsumen bisa langsung mengenali produk tape ketan yang berasal dari Banjarharjo Kabupaten Brebes.

Usaha tape ketan daun jambu daerah Banjarharjo Brebes mengalami perubahan pangsa pasar yang semula merupakan produk konsumsi pribadi menjadi produk yang dimanfaatkan sebagai oleh-oleh dengan pangsa pasar yang lebih luas. Pangsa pasar yang luas serta di ikuti dengan permintaan yang banyak tentunya menimbulkan peluang yang besar. Peluang tersebut melahirkan banyak pengusaha tape ketan pada Kecamatan Banjarharjo dengan membuat merek dagang atau label usaha tersendiri seperti data pada Tabel 1

Tabel 1. Data pengusaha tape ketan Desa Banjarharjo

\begin{tabular}{cll}
\hline No & \multicolumn{1}{c}{ Nama pemilik } & \multicolumn{1}{c}{ Nama usaha / label } \\
\hline 1 & Ibu Umar & Tape Ketan Bu Umar Kumis \\
\hline 2 & Ibu Caskini & Tape Ketan Bu Caskini \\
\hline 3 & Ibu Seri & Tape Ketan Bu Seri \\
\hline Sumber: pengusaha tape ketan Desa Banjarharjo (2020)
\end{tabular}

Usaha kuliner tape ketan daun jambu ini dari tahun ke tahun memiliki perkembangan yang cukup positif dibandingkan jenis tape lainnya di luar daerah Banjarharjo. Hasil studi serta kajian data empiris mengungkapkan adanya permasalahan dan kendala dalam mengembangkan bisnis ini, diantaranya; kendala pengolahan, kendala pemasaran yaitu belum adanya sistem kontrak yang jelas, kemasan produk tape yang kurang menarik, karakteristik produk yang memiliki daya tahan yang rendah sehingga tidak mampu untuk disimpan dalam waktu tertentu, dan kegiatan promosi yang belum optimal.

Berdasarkan uraian latar belakang di atas maka penelitian ini bertujuan untuk mengetahui kualitas produk, kepuasan pelanggan serta mencari tahu pengaruh antara kepuasan dengan kualitas produk tape ketan daun jambu di Desa Banjarharjo Kabupaten Brebes. 
Journal Economics and Management (JECMA), Volume 1, No. 1, Agustus 2021, p. 37-41

\section{LITERATURE REVIEW}

Menurut Assauri, menggambarkan bahwa kualitas produk adalah bagaimana kemampuan sebuah produk dalam melaksanakan fungsi yang diharapkan[1]. Di sisi lain, Tjiptono, bahwa kualitas produk yang dirasakan oleh pelanggan menentukan sudut pandang pelanggan terhadap kepuasan pelanggan.

Untuk mengukur kualitas produk maka diperlukan indikator. Menurut Tjiptono (2008) menyatakan bahwa dalam menilai serta mengukur kualitas sebuah produk terdapat beberapa indikator yang bisa dijadikan tolak ukur [2].

Dalam studi kasus kegiatan pemasaran sebuah produk, ada 8 dimensi yang dijadikan penilaian

a. Kinerja (Performance), yaitu ciri dari sebuah produk.

b. Fitur (Features), yaitu keunggulan yang dapat meningkatkan pengalaman dalam menggunakan produk.

c. Keandalan (Reliability), tingkat kepercayaan pelangggan terhadap suatu produk

d. Konformasi (Conformance), yaitu tingkat kesesuaian produk dengan standar yang telah ditetapkan.

e. Daya Tahan (Durability), yaitu kekuatan sebuah produk

f. Kecepatan dan kemudahan (Serviceability), yaitu kecepatan dalam memberikan pelayanan kepada konsumen

g. Estetika (Aesthetics), yaitu tampilan produk yang dapat dilihat dan dinilai dengan menggunakan panca indera (rasa, aroma, suara, dan seterusnya).

h. Persepsi terhadap kualitas (Perceived Quality), yaitu kualitas produk dilihat dari reputasi penjual[3].

Menurut Irawan (2008), pelanggan yang puas adalah pelanggan yang merasakan nilai dari produk atau jasa yang digunakan. Nilai yang diberikan oleh pelanggan merupakan apresiasi terhadap produk berkualitas, maka perasaan puas yang dialami oleh pelanggan terjadi saat pelanggan mendapatkan produk yang berkualitas. Kepuasan pelanggan ditentukan oleh ekspektasi pelanggan terhadap jasa atau produk yang dapat memenuhi kebutuhan dan keinginan mereka. Ada 5 tolak ukur yang mempengaruhi kepuasan pelanggan, yaitu kualitas produk, harga, pelayanan, emosional, dan kemudahan.

Kepuasan pelanggan menurut Tjiptono (2008), berasal dari kata kepuasan (satisfaction) berasal dari bahasa Latin "satis" (artinya cukup baik, memadai) dan "facio" (melakukan atau membuat). Kepuasan dapat diartikan sebagai "ekspresi senang yang ditunjukkan oleh pelanggan ketika produk atau jasa tersebut sesuai dengan telah sesuai dengan harapan sedangkan menurut Kotler (2009), bahwa kepuasan pelanggan ialah sebuah perasaan senang atau kecewa yang dialami seseorang setelah membandingkan kinerja (hasil) produk yang dipikirkan terhadap kinerja (hasil) yang diharapkan. Jika sebuah produk berada di bawah harapan maka akan mengakibatkan pelanggan tidak puas sedangkan ketika sebuah produk memenuhi harapan, maka pelanggan akan merasakan kepuasan. Jika kinerja melebihi harapan, pelanggan amat puas atau senang[4].

Untuk menggambarkan variabel kepuasan pelanggan secara detail dalam penelitan ini, maka peneliti menggunakan teori atau model perspektif Psikologi. Oleh karena itu untuk menegetahui sikap seseorang terhadap suatu obyek, maka dapat dianalisis melalui indikatorindikator yang dimiliki obyek tersebut. Sedangkan kepuasan adalah suatu sikap yang diputuskan berdasarkan pengalaman yang didapatkan[5].

Menurut Nigel Hill (1999), menyatakan bahwa terdapat sejumlah metode yang digunakan untuk mengukur kepuasan pelanggan adalah:

a. Survei Berkala/Survei Kepuasan Pelanggan, yaitu dapat menelusuri kepuasan pelanggan secara langsung, dengan cara para responden diberi pertanyaan

b. Analisis Pelanggan yang Hilang, yaitu dengan mengontak pelanggan yang telah berhenti 
Journal Economics and Management (JECMA), Volume 1, No. 1, Agustus 2021, p. 37-41

membeli atau sudah beralih ke pemasok lain untuk mempelajari mengapa hal ini bisa terjadi[6].

Teknik belanja siluman merupakan salah satu cara yang dapat digunakan untuk menemukan serta melaporkan kekuatan dan kelemahan produk pesaing. Para manajer dapat masuk ke dalam situasi penjualan yang dilakukan oleh pesaing serta melihat dan mengalami secara langsung perlakuan yang mereka terima ketika pesaing menerima keluhan dari konsumen serta melihat bagaimana pesaing menyelesaikan keluhan dari konsumen tersebut

Menurut Zeithaml ada 4 unsur yang dapat merubah persepsi dan ekspektasi pelanggan, yaitu sebagai berikut :

1. Testimoni yang dibagikan pelanggan dari pelanggan lainnya (word of mouth communication).

2. Ekspektasi pelanggan (personnel needs).

3. Pengalaman masa lalu (past experience)

4. Komunikasi dengan pihak eksternal (external communication) [7].

\section{METHODS}

Penelitian ini merupakan penelitian korelasional yang menghubungkan antara dua variabel atau lebih[8]. Penelitian ini bersifat kuantitatif dengan metode studi kasus, pada produk Tape Ketan Daun Jambu. Dikatakan kuantitaif karena data-data yang didapatkan diterjemahkan ke dalam bentuk angka atau numerik.

Untuk mendapatkan data yang diperlukan dalam penelitian ini, penulis melakukan penelitian pada perusahaan Tape Ketan Daun Jambu yang ada di Desa Banjarharjo Kabupaten Brebes. Populasi dalam penelitian ini adalah jumlah seluruh pelanggan Tape Ketan Daun Jambu khas Desa Banjarharjo, Kabupaten Brebes sebanyak 92 pelanggan. Sampel dalam penelitian ini pelanggan Produk Tape Ketan Daun Jambu Khas Banjarharjo, dengan menggunakan teknik sampel Acak Sederhana (Random Sampling) sebanyak 30 responden. Dalam penelitian ini, penulis melaksanakan kegiatan observasi dengan terjun langsung serta terlibat dalam seluruh kegiatan sehari-hari dengan responden yang sedang diamati atau digunakan sebagai sumber data penelitian. Dalam penelitian ini untuk mendapatkan data primer, penulis menyebar kuesioner kepada pelangan Tape Ketan Daun Jambu sebanyak 30 orang.

Skala likert adalah teknik untuk malakukan pengukuran dengan membagi kategori respon menjadi lima kategori yang mewajibkan seluruh responden untuk memilih derajat persetujuan atau ketidaksetujuan mereka terhadap beberapa pernyataan mengenai obyek stimulus[9]. Dalam penelitian ini Skala Likert dan nilai skoring yang digunakan seperti Tabel 2.

Table 2. Skala likert

\begin{tabular}{lclcc}
\hline Kualitas produk & Disingkat & $\begin{array}{c}\text { Kepuasan } \\
\text { pelanggan }\end{array}$ & Disingkat & $\begin{array}{c}\text { Skala } \\
\text { Nilai }\end{array}$ \\
\hline Sangat Baik & SB & Sangat Puas & SP & 5 \\
\hline Baik & B & Puas & P & 4 \\
\hline Kurang Baik & KB & Puas & KP & 3 \\
\hline Tidak Baik & TB & Tidak Puas & TP & 2 \\
\hline Sangat Tidak Baik & STB & Sangat Tidak Puas & STP & 1 \\
\hline Sumber: Diadaptasi dari sugiyono & & &
\end{tabular}

Teknik analisis data yang digunakan adalah Uji Validitas, Uji Relia-bilitas, Regresi Sederhana, Uji Korelasi, Uji Determinasi, dan Uji t (Uji Hipotesis). 
Journal Economics and Management (JECMA), Volume 1, No. 1, Agustus 2021, p. 37-41

\section{RESULTS AND DISCUSSION}

Kuesioner sebelum dijadikan alat ukur untuk diuji lebih lanjut diuji dulu kelayakannya melalui Uji Validitas dan Reliabilitas. Data yang dilaporkan di bawah ini merupakan data yang sudah valid dan reliable, sehingga layak dijadikan alat ukur. Oleh karena itu hasil penelitian penulis di uraikan menjadi 2 (dua) analisis, yaitu analisis deskriptif dan analisis inferensia sebagai berikut: Analisis deskriptif yaitu sebuah uraian untuk menjelaskan mengenai hasil riset secara umum, bagaimana karakteristik subyek penelitian sehubungan dengan variabel- variabel yang diteliti[10]. Sebelum dilaksanakan analisis statistik penulis melakukan pembobotan dengan memberikan skor terhadap masing-masing variabel. Pemberian pembobotan ini dilakukan pada setiap pertanyaan yang dibuat oleh penulis dalam kuesioner.

\section{CONCLUSION}

Hasil penelitian tersebut mengungkapkan bahwa terdapat pengaruh positif kuat dan siginifikan antara kualitas produk Tape Ketan daun Jambu "Dio" terhadap kepuasan pelanggan.

\section{REFERENCES}

[1] S. L. Nasution and D. A. Limbonong, Christine Herawati Ramadhan, "Pengaruh Kualitas Produk, Citra Merek, Kepercayaan Kemudahan Dan Harga Terhadap Keputusan Pembelian Pada E-Commerce Shopee," J. Ecobisma, pp. 43-53, 2020.

[2] F. Tjiptono, Aplikasi Praktis Riset pemasaran. Jakarta: PT. Gramedia Pustaka Utama, 2007.

[3] C. G. Tjiptono F, Pemasaran Strategik Mengupas Pemasaran Strategik, Branding Strategy, Customer Satisfaction, Strategi Kompetitif, II. Yogyakarta, 2012.

[4] Morgan, Marketing Insights From AtoZ, vol. 53, no. 9. 2003.

[5] C. H. Lovelock and J. Wirtz, "Services Marketing - People, Technology, Strategy," in Harvard Business Review, 2010.

[6] R. M. Nigel Hill, John Brierley, How to Measure Customer Satisfaction. Burlington: Gower, 1999.

[7] V. A. Zeithaml, "Consumer Perceptions of Price, Quality, and Value: A MeansEnd Model and Synthesis of Evidence," J. Mark., 1988, doi: $10.1177 / 002224298805200302$.

[8] Sugiyono, Metode Penelitian Manajemen. Bandung: Alfabeta, 2016.

[9] A. Joshi, S. Kale, S. Chandel, and D. Pal, "Likert Scale: Explored and Explained," Br. J. Appl. Sci. Technol., vol. 7, no. 4, pp. 396-403, 2015, doi: 10.9734/bjast/2015/14975.

[10] Sugiyono and Republik Indonesia, Metode Penelitian Kuantitatif \& kualitatif. 2010. 